\title{
Letter to the Editor regarding Hubacek et al.'s report 'Lack of an association between SNPs within the cholinergic receptor genes and smoking behavior in a Czech post-MONICA study"
}

\author{
Ahmet Müderrisoglu and Melih Babaoglu \\ Department of Pharmacology, Medical Faculty, Hacettepe University, Ankara, Turkey.
}

Received: July 12, 2017; Accepted: September 19, 2017.

In the article Hubacek et al. (2014) published in this journal, a genetic variant of CHRNA3 was examined. We think that molecular sizes for the PCR product and the restriction fragments for the analysis of rs578776 were presented erroneously in Table 1 . In this table, it said that the PCR product encompasses 167 base pairs (bp) and the restriction fragment sizes are $100 \mathrm{bp}$ and $67 \mathrm{bp}$ for the $\mathrm{C}$ allele when the PCR product was cut by the enzyme NlaIII. However, the actual size of the PCR product should be $146 \mathrm{bp}$, and restriction fragments should be $82 \mathrm{bp}, 54 \mathrm{bp}$ and $10 \mathrm{bp}$ for the $\mathrm{C}$ allele; and $92 \mathrm{bp}$ and $54 \mathrm{bp}$ for the $\mathrm{T}$ allele. In Figure 1 we describe here the PCR product and the restriction fragments predicted by using the University of California Santa Cruz (UCSC) Genome Browser In Silico PCR Tool with the primers 5'-TTC TTT ACT GGG TCT AAA GGG CTA TGC C-3', 5'-ATC CAC CCA GTT TAT GGT GTA CTA AG-3' and the restriction enzyme NlaIII, as used in Table 1 of the article. We also performed an in silico restriction analysis using NEBcutter V2.0. Figure 2 demonstrates an actual example of the restriction pattern obtained in our laboratory.

Since other researchers who may wish to apply the methodology in the future may be misled by the erroneous information published, we would like to bring this error to attention for a possible correction.

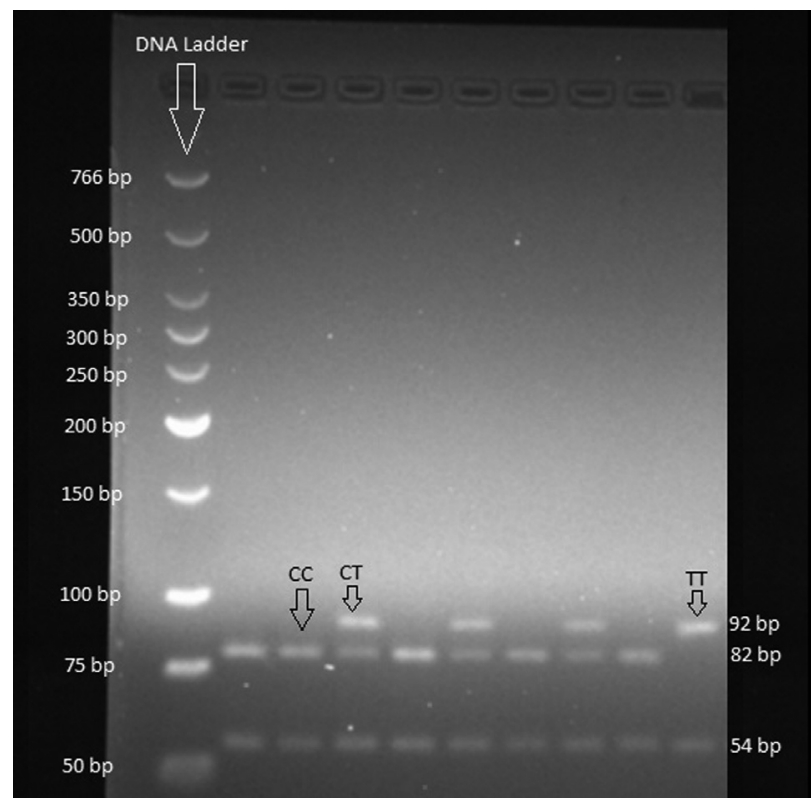

Figure 2 - The actual restriction pattern of the PCR product for CHRNA3 rs 578776 by using NlaIII.

\section{Reference}

Hubacek JA, Lanska V and Adamkova V (2014) Lack of an association between SNPs within the cholinergic receptor genes and smoking behavior in a Czech post-MONICA study. Genet Mol Biol 37(4):625-630.

\begin{tabular}{|c|}
\hline TTCTTTACTGGGTCTAAAGGGCTATGCCTCCATTTCAGAGAGCTTCAACT \\
\hline ACTTCTCTTGCATACTTCTAAATTATAC $(\underline{C} /)^{\mathrm{a}} \mathrm{ATG}^{\mathrm{b}} \downarrow \mathrm{AGAAATCATG}^{\mathrm{b} \downarrow} \downarrow \mathrm{CCTAGTTA}^{\mathrm{A}}$ \\
\hline TTCATTGTTAATATAACTGTCTTAGTACACCATAAACTGGGTGGAT \\
\hline
\end{tabular}

Figure 1 - The genetic sequence of the PCR product of $146 \mathrm{bp}$ for the analysis of CHRNA3 rs578776 with the restriction sites for NlaIII. (chromosome 15 :

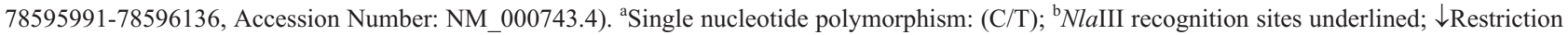
Points. 


\section{Internet Resources}

University of California Santa Cruz (UCSC) Genome Browser In Silico PCR Tool: https://genome.ucsc.edu/cgi-bin/hgPcr (Accessed on July 7, 2017)
NEBcutter V2.0: http://nc2.neb.com/NEBcutter2/ (Accessed on July 7,2017 )

Associate Editor: Carlos F. M. Menck

License information: This is an open-access article distributed under the terms of the Creative Commons Attribution License (type CC-BY), which permits unrestricted use, distribution and reproduction in any medium, provided the original article is properly cited. 